\title{
The American Sociologist
}

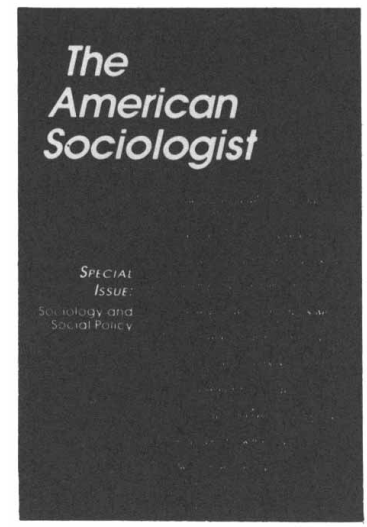

James L. McCartney, editor

(University of Missouri, Columbia)

Examines the history, current status, and future prospects of sociology as a profession and discipline. The journal emphasizes the comings and goings of the profession, and focuses on how sociologists have shaped or try to shape social policy and the intellectual issues of the age. It also publishes professional opinions, special features, interviews, and review essays.

\section{Recent articles Include:}

Howard S. Becker discusses graduate education. James S. Coleman reviews the role of social policy research in society and in sociology. Richard A. Berk suggests the possible consequences of AIDS.

Sylvia Kenig discusses the use of theory in applied sociology.

Walter Gove argues that sociobiology misses the mark.

David Jennese anticipates future patterns of support for sociology.

Bruce Wiegand suggests the political considerations of studying tax compliance.

\section{Published Quartarly}

Subscription rates:

Individuals: $\$ 35 / \mathrm{yr} ; \$ 60 / 2 y r s ; \$ 80 / 3 y r s$. Institutions: $\$ 55 / y r ; \$ 95 / 2 y r s ; \$ 130 / 3 y r s$.

Domestic first-class mail add $\$ 12 / \mathrm{yr}$.

Forelgn surface mail add $\$ 12 / y r$.

Foreign airmail add $\$ 25 / y r$. 
Now available in paper

\section{Power and Protest in the Countryside}

Studies of Rural Unrest in Asia, Europe, and Latin America Robert P. Weller and Scott E. Guggenheim, editors

"Constitutes an important and timely addition to the literature on peasant rebellion; wisely, the editors have been eclectic in drawing from some of the leading historians, anthropologists, political scientists, and sociologists active in the field an analysis of the forms that rural violence has taken through the past three centuries."-Pacific Affairs

Contributors: Charles Tilly, Robert Wasserstrom, Joel S. Migdal, Michael Adas, William Roseberry, Ralph Thaxton, Theda Skocpol, Sidney W. Mintz 1989 (1982). viii, 212 pages, notes, references, index. LC 82-12991, ISBN 0-8223-0483-X, cloth, \$34.95 ISBN 0-8223-0895-9, paper, $\$ 10.95$

Duke University Press 6697 College Station

Durham, North Carolina 27708 


\section{THE ASSOCIATION OF AMERICAN UNIVERSITY PRESSES DIRECTORY 1988-1989}

The Association of American University Presses has for over fifty years worked to encourage the dissemination of scholarly research and ideas. Today the ninety-nine members of the AAUP annually publish nearly 7,000 books and more than 400 periodicals. This directory offers a detailed introduction to the structure and staff of the AAUP and to the publishing programs and personnel of its member presses.

Among its useful features are

-a detailed description of each press with a summary of its publishing program and a list of the names and responsibilities of its key staff;

-complete address information, including telephone, fax, telex, cable numbers, and electronic mail addresses;

-a subject guide, with 136 categories, indicating which presses publish in a given area;

—an alphabetical index of all listed personnel;

- a listing of key contact persons at each press;

-advice to authors on the submission of manuscripts.

As an introduction and guide to the world of university presses, this directory will be an essential reference and resource to anyone who is or wants to be involved in scholarly publishing.

Order No. 0-945103-01-8 Paper \$11.95 224pp

Distributed for the Association of American University Presses

\section{THE UNIVERSITY OF CHICAGO PRESS}

Dept. CE /5801 South Ellis Avenue Chicago, IL 60637 


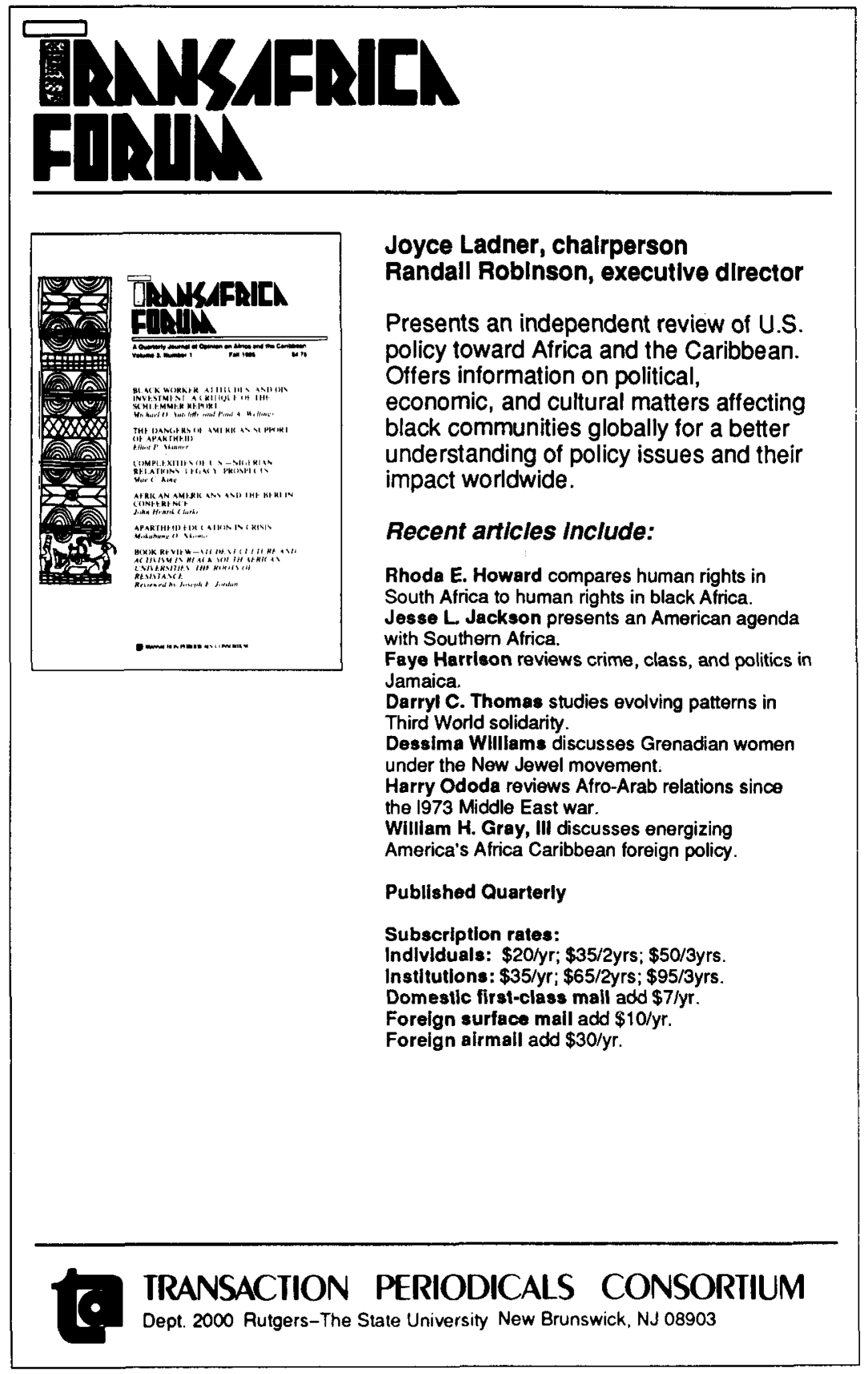


MANAGING EDITORS

James Q. Graham, Bowling Green State University

Robert P. Swierenga, Kent State University

ASSOCIATE EDITORS

William $\mathrm{O}$. Aydelotte, University of Iowa

Lee Benson, University of Pennsylvania

Allan G. Bogue, University of Wisconsin

Warren Miller, Arizona State University

EXECUTIVE EDITOR Rachael Rockwell Graham

BOARD OF EDITORS

Barbara Anderson, University of Michigan

Ellen Dwyer, Indiana University

William Clagett, Florida State University

Heinz Eulau, Stanford University

Roderick Floud, University of London

David W. Galenson, University of Chicago

Alice Goldstein, Brown University

Myron P. Gutmann, University of Texas at Austin

David I. Kertzer, Bowdoin College

J. Morgan Kousser, California Institute of Technology

Robert C. Liebman, Portland State University

Patrick Manning, Northeastern University

Terrence McDonald, University of Michigan

Leslie Moch, University of Michigan, Flint

Karen Orren, University of California, Los Angeles

John Padgett, University of Chicago

Donald Parkerson, East Carolina State University

Richard Steckel, Ohio State University

John J. TePaske, Duke University

Susan Cott Watkins, University of Pennsylvania

Ian Winchester, Ontario Institute for Studies in Education

SSHA EXECUTIVE DIRECTOR

Howard W. Allen, Southern Illinois University 
New from Duke University Press

\section{The Mind Is Not the Heart}

Recollections of a Woman Physician

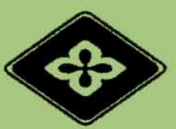

E V A J. S A L B E R

"The Mind Is Not the Heart is a book which the woman's movement, those who know themselves to be snarled-up with racism in one way or another, and the medical profession will read with astonishment, for in its quiet way it makes us all take a steady look at our late-20th century selves. There is no moralising or detachment. Eva Salber has been too busy living her days to preach from the sidelines. Moving from her beloved South Africa to Britain, to New England and then to North Carolina adds a saga-like quality to her narrative. It is a remarkable journey, compassionate, intelligent, engrossed. The Mind Is Not the Heart is a book which tells us what to live for, and what not to miss wherever we happen to be."-Ronald Blythe, author of Akenfield:Portrait of an English Village and Divine Landscapes

272 pages. ISBN 0-8223-0910-6 \$24.95

Duke University Press 6697 College Station

Durham, North Carolina 27708 